The objective of I.B.P. is to ensure world-wide study of (a) organic production on the land, in fresh waters, and in the seas, and the potentialities and uses of new as well as of existing natural resources, and (b) human adaptability to changing conditions. The program is limited to basic biological studies that will benefit from international collaboration, and are urgent because of the rapid rate of changes occurring in all environments.

Twenty-four of the forty-three countries that support I.B.P. have established a National Committee, and the remainder have appointed National Correspondents. Canada's Co-ordinating Committee has set up seven sub-committees, each under a chairman who is nationally-often internationally-known in the appropriate field. Dr. I. C. M. Place is the Chairman of Canada's subcommittee on Productivity of Terrestrial Communities. Canadian foresters in university, government, and industry are active in working groups set up under this sub-committee and, also, under those on Production Processes, Conservation of Terrestrial Communities, and the Use and Management of Biological Resources.

The Canadian Co-ordinating Committee, of which I am a member, has met twice with the sub-committee chairmen to decide on policy and to prepare a budget. In general, Canada's policy is to co-ordinate results of biological research now conducted by different agencies and to present these results as a unified contribution toward I.B.P. aims. It is not anticipated that Canadian research organizations will be setting up new projects for the sole purpose of answering questions raised by I.B.P.

The National Research Council is providing a small budget to cover a limited amount of travel required to co-ordinate this program.

I consider this a very worthwhile international project, and I implore members of the C.I.F. to support it by joining Working Groups of the appropriate sub-committees, if they are requested.

I will gladly arrange to provide more detailed information, if requested, and thank you for your kind attention.

D. R. REDMOND

\title{
Regional Organization of Department of Forestry
}

Seven regional directors, and eight program co-ordinators at Ottawa, have been appointed by the Civil Service Commission.

The regional directors will be responsible for regional research programs in forestry and forest insects and diseases, formerly conducted by separate branches of the department, as well as for liaison with provincial governments relating to research and federal-provincial forestry agreements, and with the forest products industries.

The new regional organizations provide for full integration and co-ordination of research and other departmental services in the region, and are designed to improve co-operation and contacts with provincial forest authorities, forest industries, and the universities.

Program co-ordinators will plan and develop a national relationship between the regional programs of research, and provide scientific leadership and functional guidance to the regional research establishments. They will assess national and international research developments and their relation to Canadian 
forestry problems. In addition, they will consult with and advise forest industries and associations regarding research requirements.

The regional directors appointed are:

Dr. W. J. Carroll, 42, officer-in-charge, forest entomology and pathology laboratory, Corner Brook, Nfld., to be director, Newfoundland Region, with headquarters to be determined; Dr. I. C. M. Place, 44, officer-in-charge, Petawawa forest experiement station, Chalk River, Ont., to be director, Maritimes Region, with headquarters at Fredericton, N.B.; Dr. Lionel Daviault, 60 , officer-in-charge, forest entomology and pathology laboratory, Sillery, Que., to be director, Quebec Region, with headquarters at Sillery; Dr. R. M. Belyea, 45, officer-in-charge, forest entomology and pathologyi laboratory, Fredericton, N.B., to be director, Ontario Region, with headquarters at Sault Ste. Marie; Clarence C. Thomson, 53, district forest officer at Winnipeg, Man., to be director, Manitoba-Saskatchewan Region, with headquarters at Winnipeg; Dr. G. P. Thomas, 44, officer-in-charge, forest entomology and pathology laboratory, Calgary, Alta., to be director, Alberta, Northwest Territories and Yukon Region, with headquarters at Calgary; Raymond R. Lejeune, 49, officer-in-charge, forest entomology and pathology laboratory, Victoria, B.C., to be director, British Columbia Region, with headquarters at Victoria.

Appointments of program co-ordinators at Ottawa are:

Silviculture-A. Bickerstaff, 50, from associate director, forest management research; provincial agreements-D. A. S. Dyer, 45; pathology-Dr. V. J. Nordin, 40, from associate director, forest pathology research; insect and disease survey-R. M. Prentice, 44; forest management-R. G. Ray, 58; entomology-W. A. Reeks, from officer-in-charge, forest entomology and pathology laboratory, Saulte Ste. Marie, Ont., to take up new duties at Ottawa; tree biology (botany)-Dr. J. S. Rowe, 46, from head, ecology section, forest management research; forest products-Dr. H. Schwartz, 49, from superintendent, Ottawa forest products laboratory.

DEPARTMENT OF Forestry

National Committee on Forest Land

Establishment of an Advisory Committee on Forest Land was announced on Oct. 4, 1965 by federal forestry minister Maurice Sauvé. Formation of this committee is the result of a unanimous recommendation of federal and provincial delegates interested in forest land classification at a national meeting held in January of this year.

Membership of the committee consists of a delegate from each of the provinces, the forestry faculties of the universities, and the regional offices of the Department of Forestry of Canada. Represented, as well, are the National Soil Survey of Canada, the Department of Agriculture, the National Parks and Canadian Wildlife Services of the Department of Northern Affairs and National Resources, and the Canada Land Inventory of ARDA.

The committee will examine, review and make recommendations on systems of land classification development for use at national or regional levels, with particular attention to the correlation of inter-provincial programs. It will investigate and make recommendations on a basis for sound management and rational use of wildlands. 